Abstracta Iranica Abstracta Iranica

Revue bibliographique pour le domaine irano-aryen

Volume 27 | 2006

Comptes rendus des publications de 2004

\title{
The Drowned Book: Ecstatic and Earthy Reflections of Bahauddin, the Father of Rumi. San Francisco, HarperSanFrancisco, 2004, xli + 149 p.
}

\section{Franklin Lewis}

\section{(2) OpenEdition}

1 Journals

\section{Édition électronique}

URL : http://journals.openedition.org/abstractairanica/6213

DOI : 10.4000/abstractairanica.6213

ISSN : 1961-960X

Éditeur :

CNRS (UMR 7528 Mondes iraniens et indiens), Éditions de l'IFRI

\section{Édition imprimée}

Date de publication : 15 mai 2006

ISSN : 0240-8910

\section{Référence électronique}

Franklin Lewis, "The Drowned Book: Ecstatic and Earthy Reflections of Bahauddin, the Father of Rumi. San Francisco, HarperSanFrancisco, 2004, xli + 149 p. », Abstracta Iranica [En ligne], Volume 27 | 2006, document 267, mis en ligne le 02 janvier 2007, consulté le 25 septembre 2020. URL : http:// journals.openedition.org/abstractairanica/6213; DOI : https://doi.org/10.4000/abstractairanica.6213

Ce document a été généré automatiquement le 25 septembre 2020.

Tous droits réservés 


\title{
The Drowned Book: Ecstatic and Earthy Reflections of Bahauddin, the Father of Rumi. San Francisco, HarperSanFrancisco, 2004, xli + $149 \mathrm{p}$.
}

\author{
Franklin Lewis
}

1 American poet Coleman Barks first began collaboration in the early 1980s with John Moyne (Javād Mo'inn), emeritus professor of linguistics and computer science, to produce translations of the poetry of Jalāl al-Dīn Rūmī. Without apparently ever learning Persian himself, Barks has made a phenomenally successful career over the past two decades of "translating" or "versioning" Rūmī, collaborating with Moyne (who works from the Persian) and others (some working from existing Turkish translations of the Persian), and sometimes re-working the existing scholarly translations of Nicholson and Arberry.

2 The method followed for the current book of selected excerpts from the Ma'âref of Rūmī's father, Bahā' al-Dīn Valad, does not lead to "a word-for-word, 'faithful' translation" (xxix), and makes the book quite unsuitable for scholarly use. Moyne first "selects and translates excerpts from Bahauddin's Persian prose into English with some explanatory notes, interpretations and minimal changes to make the archaic language and theological terms understandable to general English-speaking readers". Barks then undertakes a "second translation", trying "to sense something like a presence moving within the images and ideas". This process of "mystical play" is ideally accomplished "not with the mind but with an emptiness in the soul" and an "attunement with other presences", and is admittedly "not scholarly work" (xxix). Samples of Moyne's "literal translation" juxtaposed with Barks' ultimate version document the procedure ( $\mathrm{xxx}$ xxxii). 
3 The introduction - consisting of "Bahauddin's Maarif" (xv-xxvii) and "A Note on Translation and Versions of Sama" (xxix-xxxvii) written jointly by Moyne and Barks, and "The Manuscripts" (xxxix-lv), written by Moyne - is perhaps the most academic presentation in the score of Rūmì books with which Barks has been associated. The English excerpts, each given a thematic heading, read smoothly, and add to the material from Bahā' al-Dīn previously translated by Arberry, followed by a short section of impressionistic, "freewheeling" (3n23) commentary by Barks (133-48).

INDEX

Thèmes : 8 . Soufisme

nompropre Rumi, Bahā' al-Din Valad

\section{AUTEURS}

FRANKLIN LEWIS

University of Chicago 